\title{
Microclimate modification to manage yellow rust incidence in wheat
}

\author{
SARABJOT KAUR SANDHU* AND L .K. DHALIWAL
}

School of Climate Change and Agricultural Meteorology, Punjab Agricultural University, LUDHIANA (PUNJAB) INDIA

\section{ARITCLE INFO}

Received : 07.03 .2016

Revised : 15.08 .2016

Accepted : 29.08.2016

\section{KEY WORDS :}

Canopy temperature, Relative humidity, Wheat, Yellow rust, Humid thermal ratio
*Corresponding author:

Email : skchahal@pau.edu

\section{ABSTRACT}

The field experiment was conducted during Rabi seasons of 2012-13 and 2013-14 at the Research Farm, School of Climate Change and Agricultural Meteorology, Punjab Agricultural University, Ludhiana. Wheat varieties HD 2967, PBW 550 and PBW 343 were sown under two row direction viz., North-South (N-S) and East-West (E-W). Yellow rust incidence was recorded at weekly intervals. Among different row direction the disease incidence was higher under $\mathrm{N}-\mathrm{S}$ row direction as compared to $\mathrm{E}-\mathrm{W}$ row direction during both the years. Among three varieties HD 2967 was highly resistant to yellow rust. During both the years maximum temperature, minimum temperature and sunshine hours were positively correlated whereas morning and evening relative humidity were negatively correlated with yellow rust incidence. Highly significant value of $\mathbf{R}^{2}(0.95$ and 0.93) was found when maximum meteorological parameters were combined in PBW 343 in crop sown under North-South and East-West row direction, respectively

How to view point the article : Sandhu, Sarabjot Kaur and Dhaliwal, L.K. (2016). Microclimate modification to manage yellow rust incidence in wheat. Internat. J. Plant Protec., 9(2) : 450-454, DOI : 10.15740/HAS/IJPP/9.2/450-454. 